\title{
SETTING THE STANDARDS FOR A NEW SCIENCE: EDWARD SCHÄFER AND ENDOCRINOLOGY
}

\author{
by \\ MERRILEY BORELL*
}

\begin{abstract}
FollowING Brown-Séquard's report in 1889 of the rejuvenating effects of injections of extracts of the testes, physicians and physiologists began to search for other potent "internal secretions" in animal tissues. They expected to be able to isolate powerful new drugs which would be useful in the treatment of a variety of intractable diseases. Remission of conditions treated by a series of such injections reinforced that expectation. Myxoedema yielded to treatment by thyroid extract, and physicians hoped to be able to cure diabetes by injections of pancreatic extract. The actual discovery of these hypothetical substances was not so straightforward, however. The criteria of remission were not well defined, and the physiological responses to these extracts were unknown.
\end{abstract}

Systematic investigation of the physiological and pharmacological effects of organ extracts was undertaken in Britain by Edward Schäfer (1850-1935), Professor of Physiology at University College London. Schäfer encouraged his students and colleagues to study animal extracts using standard physiological techniques, measuring blood pressure and heart rate, as well as change in organ volume, following administration of an extract. Like Brown-Séquard, Schäfer expected that any tissue might contain a powerful new drug. Nonetheless, he was reluctant to place the burden of proof of its existence on the cure of a specific disease. He sought, therefore, to discover measurable physiological responses with which to detect and assay these substances.

When, in 1905, Schäfer's successor and former associate at University College, Ernest Starling, introduced the new term "hormone" to specify the blood-borne chemical messengers discovered by these laboratory techniques, Schäfer had already been studying internal secretions for over ten years. In his new post at the University of Edinburgh, Schäfer was encouraging Francis Marshall and William Jolly in their study of the role of the internal secretion of the ovary in the maintenance of oestrus and pregnancy. Seven years later, his student Swale Vincent wrote the first English

*Merriley Borell, Ph.D., Wellcome Lecturer in the History of Medicine, Department of History, University of Edinburgh, William Robertson Building, George Square, Edinburgh EH8 9JY.

This paper was presented at the XVth International Congress of the History of Science held in Edinburgh, August, 1977. I wish to thank Mr. Eric Freeman and Miss Brenda Sutton for their frequent assistance during my consultation of the Sharpey-Schafer Collection while a Research Fellow at the Wellcome Institute for the History of Medicine, and Professor Diana Long Hall for her helpful comments on an earlier draft of this paper. I am grateful to the Wellcome Trust for their very generous support of this work. 


\section{Edward Schäfer and endocrinology}

textbook on internal secretions. As an active member of the Royal Society, the Physiological Society, and the British Association for the Advancement of Science, Schäfer continued to encourage further support of laboratory investigations of these substances.

In this paper, I consider Schäfer's role in the emergence of the new field of endocrinology, and I emphasize his contributions to the establishment of scientific medicine in Britain. In particular, I consider his position as critic when, during the early years of this century, following a series of promising investigations, careful study of the properties of animal extracts was threatened by the over-zealous prescription of these preparations by practising physicians.

Reflecting the sentiments of many of his scientific colleagues, the American anatomist Herbert McLean Evans (1882-1971) claimed in 1933 that endocrinology "suffered obstetric deformation in its very birth."1 Nonetheless, during the previous decade endocrinology had become a biochemical science. One after the other of the ductless glands was finally yielding its "internal secretion" to physiological and chemical analysis. This was a goal long aspired to by its earliest advocates.

In 1905, when introducing the new term "hormone" before the Royal College of Physicians, the physiologist Ernest Starling (1866-1927) had proclaimed: “. . . within a reasonable space of time, we shall be in possession of chemical substances which are normal physiological products, and by means of which we shall be in a position to control not only the activities but also the growth of a large number of organs of the body."2 In that year, Starling had heralded not only a growing faith in the ultimate fruits of scientific investigation for, the practice of medicine, but also a new era in physiology, where not only nervous impulses but also chemical signals would be the object of intensive investigation. His senior colleague, the first English investigator to embrace the theory of internal secretion, Sir Edward Sharpey-Schafer (1850-1935), later emphasized the changed perception of the central problems of his profession by calling this the "New Physiology"."

\footnotetext{
${ }^{1}$ Herbert M. Evans, 'Present position of our knowledge of anterior pituitary function,' J. Am. med. Ass., 1933, 101: 425-432, p. 425. This comment has been recalled by Sir Humphry Davy Rolleston in The endocrine organs in health and disease with an historical review, Oxford University Press, 1936, p. 26; by Hans Lisser in 'The Endocrine Society: the first forty years (1917-1957)', Endocrinology, 1967, 80: 7; and by F. G. Young in 'The evolution of ideas about animal hormones', in Joseph Needham (ed.), The chemistry of life, Cambridge University Press, 1971, pp. 125-155 p. 143. The full sentence reads: "Endocrinology, which suffered obstetric deformation in its very birth by the extravagant claim of the septuagenarian Brown-Sequard that he had magically restored his youth with testicular substance, has continued to suffer the same sort of obloquy through similar claims of the modern Steinach school, whereas to be an endocrinologist among the practising profession today means too often to be primarly [sic] concerned with making fat ladies thin." Evans held the chair of anatomy at the University of California, Berkeley. This judgment was rendered to the Congress of American Physicians and Surgeons.

'Ernest Henry Starling, "The Croonian Lectures on "The chemical correlations of the functions of the body"', Lancet, 1905, ii: 339-341, 423-425, 501-503, 579-583; p. 339. Starling was Jodrell Professor of Physiology at University College, London.

' Sir E. Sharpey-Schafer, 'Endocrine physiology', Ir. J. med. Sci., 1931, 6th series, no. 69, pp. 483-505, p. 484. I thank Dr. Judith P. Swazey and Dr. Karen Reeds for drawing my attention to the term "New Physiology". Sharpey-Schafer was Professor of Physiology at the University of Edinburgh. He preceded Starling as Jodrell Professor at University College.
} 


\section{Merriley Borell}

By the 1930s when Evans addressed the Congress of American Physicians and Surgeons the validity of the approach signalled by Starling was apparent, and endocrinologists looked back with pride on the successes of the previous decade. Insulin had been isolated, and the hormones of the ovary, pituitary, and adrenal glands were gradually being recovered and studied." As a result of these discoveries, biologists were rapidly becoming aware of the complexity of regulatory mechanisms within living organisms, and the philosophical assumptions underlying biological research were being re-evaluated. A host of new substances had come under investigation, and as Sharpey-Schafer proudly noted in 1933, the character of physiological research had altered markedly in less than thirty years. These transitions were due in no small part to the recognition of minute amounts of potent chemicals contained in animal tissues, a recognition accomplished in the 1890 s under conditions of which SharpeySchafer, Starling, and most certainly Evans were less than proud.

In 1889, the scientist C.-E. Brown-Séquard (1817-1894) had suggested, by means of physiological arguments, that the human body might be rejuvenated by injections of extracts of the testicles of young animals. ${ }^{5}$ In 1891, he and his assistant Arsène d'Arsonval (1851-1940), encouraged by the response of their medical colleagues, had extended the claim further, arguing that all tissues give something special to the blood, either an active principle or principles which might be extracted and used by physicians to treat a variety of intractable diseases. ${ }^{6}$ Elsewhere I have described Brown-Séquard's experiments, the rise of organotherapy, the strategy of the search for internal secretions, and the subsequent discovery in 1902 by Starling and William Bayliss (1860-1924) of the prototype hormone secretin.?

By the second decade of the twentieth century, in spite of the over-zealous prescription of organ extracts by practitioners and the subsequent development of an uneasy alliance between physicians and laboratory scientists, the study of internal secretions came to prominence. The first textbooks were written between 1910 and 1916, and shortly thereafter, societies were formed, journals founded, and the methods, concepts, and underlying problems of this new body of knowledge standardized. ${ }^{8}$ This specialty, dealing with the physiological functions and chemical products of the ductless glands was called endocrinology. By the 1930s it was popularly claimed that the endocrine glands are "arbiters of our health, our stature, and our morals"."

- Although active extracts of the adrenal and thyroid were prepared in the 1890 s, active preparations of insulin and the hormones of the sex glands and pituitary were not obtained until the 1920s.

${ }^{5}$ Cf. Merriley Borell, 'Brown-Séquard's organotherapy and its appearance in America at the end of the nineteenth century', Bull. Hist. Med., 1976, 50: 309-320.

- See Brown-Séquard's English account: C. E. Brown-Séquard, 'On a new therapeutic method consisting in the use of organic liquids extracted from glands and other organs', Lancet, 1893, i: 1145-1147, 1212-1214.

' Merriley Borell, 'Organotherapy, British physiology, and discovery of the internal secretions', J. Hist. Biol., 1976, 9: 235-268, and 'Origins of the hormone concept: internal secretions and physiological research, 1889-1905', unpublished Ph.D. diss., Yale University, 1976.

8 The first text was that of Artur Biedl, Innere Sekretion: Ihre physiologischen Grundlagen und ihre Bedeutung für die Pathologie, Berlin, Urban \& Schwarzenberg, 1910. Works by Swale Vincent, Edward Schäfer, and Eugène Gley rapidly followed. See Rolleston, op. cit., note 1 above, p. 1, for a list of journals devoted to this subject and their dates of founding.

- Untitled cutting (p. 241, presumably relating to conferring title of Emeritus Professor on E. A. Sharpey-Schafer) in Ivan de Burgh Daly Collection (Ms. 6353. File A.4). Wellcome Institute for the History of Medicine, London. 


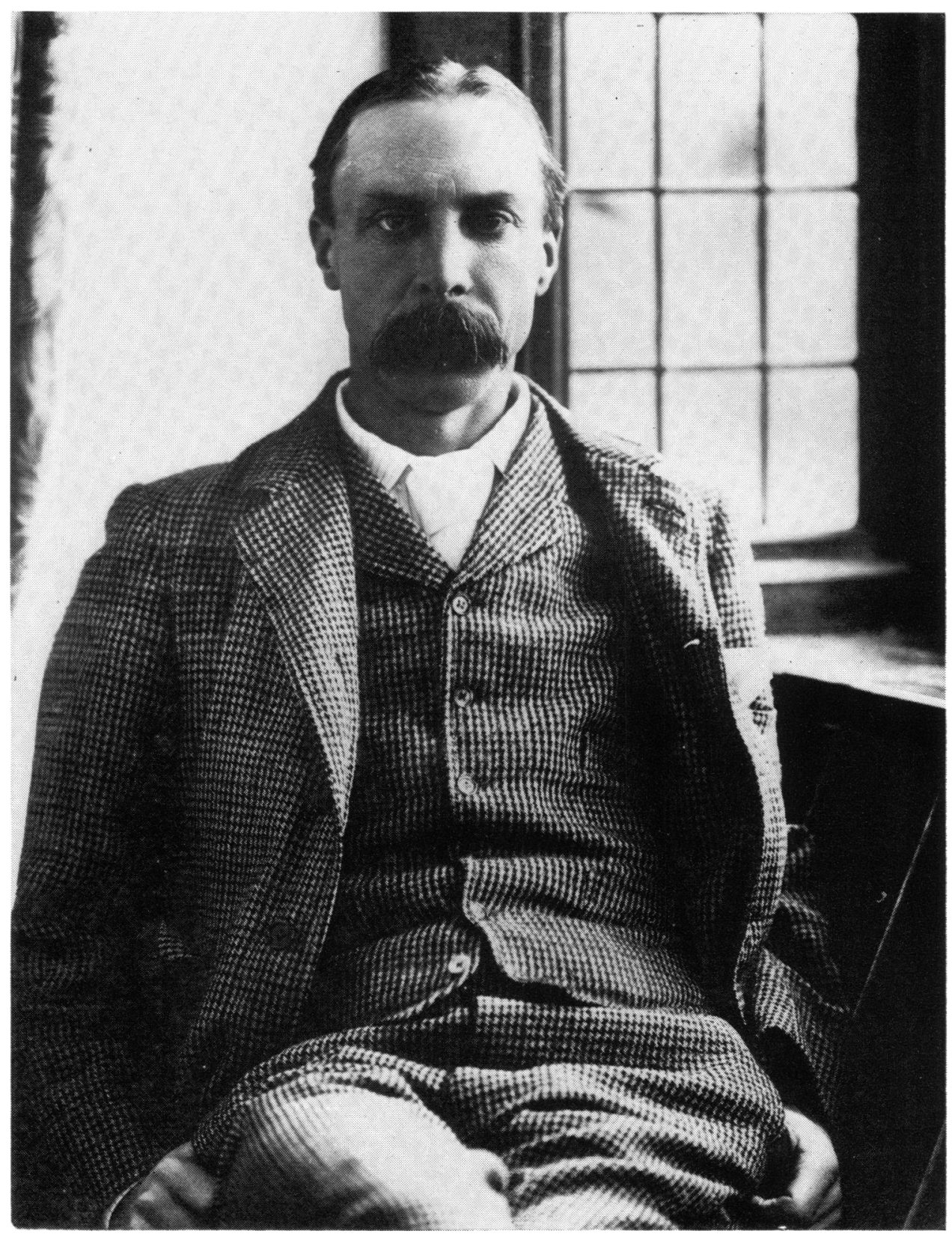

Sir Edward Sharpey-Schafer (1850-1935), circa 1895, during his final years at University College. (Reproduced by courtesy of the Wellcome Trustees.) 


\section{Edward Schäfer and endocrinology}

The establishment of endocrinology in Britain was due largely to the efforts of one man, Edward Schäfer (after 1918 Sir Edward Sharpey-Schafer), Professor of Physiology at University College London until 1899, then Professor of Physiology at the University of Edinburgh until 1933. ${ }^{10}$ Schäfer's role in initiating and guiding the growth of endocrinology in Britain is intimately bound up with the process of legitimation of a subject whose very foundations defied demonstration by standard physiological techniques for nearly thirty years. ${ }^{11}$ Since the criteria of remission of many of the conditions treated with organ extracts were unclear, there were endless debates over the reliability of clinical data in proving the existence of special substances, that is internal secretions or hormones, in these preparations. These debates were complicated by the fact that specific physiological effects could not be demonstrated for most of these extracts. Investigators, like Schäfer, besieged by conflicting observations and interpretations from the clinic and the laboratory, sought, with very great difficulty, to define the criteria upon which the new field ought to be established. It is to the demonstration of the precise physiological effects of organ extracts, that Schäfer committed himself, after 1893, when the vasopressor effects of adrenal extract were brought to his attention by the clinician George Oliver (1841-1915). ${ }^{12}$

Like most of his colleagues in the Physiological Society, Schäfer sought to establish a rational scientific medicine in Britain. ${ }^{13}$ A sound endocrine science became one of the pivotal issues in the attainment of this goal. As endocrine dysfunction provided

${ }^{10}$ The most useful biographies written by contemporaries are those by Charles Scott Sherrington, 'Sir Edward Sharpey-Schafe,, 1850-1935', Quart. J., exp. Physiol., 1935, 25: 99-104; idem., 'Sir Edward Sharpey-Schafer and his contributions to neurology', Edinb. med. J., 1935, 42 (n.s.): 393406; and Leonard Hill, 'Sir Edward Albert Sharpey-Schafer 1850-1935', Obit. Not. Fell. R. Soc. Lond., 1932-35, 1: 401-407. See also obituaries in Br. med. J., 1935, i: 741-742, Lancet, 1935, i: 843-845, and Nature, Lond., 1935, 135: 608-610. Douglass W. Taylor's biography in C. C. Gillispie (ed.), Dictionary of scientific biography, 1975, 12: 355-357, provides a concise summary of Schäfer's life and work. A complete list of the publications of Sharpey-Schafer may be found in the Ivan de Burgh Daly Collection at the Wellcome Institute for the History of Medicine, London. Daly, Schäfer's successor at Edinburgh, compiled an interesting selection of Sharpey-Schafer memorabilia. That collection, along with the extensive array of diaries, scrapbooks, reprints, photographs, and correspondence in the Sharpey-Schafer collection itself, provides an important source for study of early twentieth-century British physiology. In addition to the sources at the Wellcome Institute, the University of Edinburgh holds a small collection of Sharpey-Schafer papers. Most of these relate to the International Physiological Congress of 1923, although Schäfer's original vivisection licence (1876) is among the documents preserved with his departmental correspondence. Schäfer, like his predecessor William Rutherford, left his library to the University of Edinburgh.

11 For an examination of the crisis in endocrinology in the 1920s, see Diana Long Hall, 'The critic and the advocate: contrasting British views on the state of endocrinology in the early 1920s', $J$. Hist. Biol., 1976, 9: 269-285; and Thomas F. Glick, 'On the diffusion of a new specialty: Marañon and the "crisis" of endocrinology in Spain', ibid., pp. 287-300.

12 See Borell, 'Organotherapy ...', op. cit., note 7 above, pp. 255-268, and 'Origins of the hormone concept', op. cit., note 7 above, ch. 4, for a discussion of Schäfer's research programme.

13 For the early history of the Physiological Society, consult Sir Edward Sharpey-Schafer, History of the Physiological Society during its first fifteen years 1876-1926, Cambridge University Press, 1927; Richard D. French, Antivivisection and medical science in Victorian society, Princeton University Press, 1975; and idem., 'Some problems and sources in the foundations of modern physiology in Great Britain', Hist. Sci., 1971, 10: 28-55. For clear expositions of the preferred relationship between science and medicine as understood by members of this group, see Sir Edward Sharpey Schafer, 'The position of physiology in medicine', Edinb. med. J., 1919, 22 (n.s.): 144-155; idem, 'Victor Horsley Memorial Lecture on the relations of surgery and physiology', Br. med. J., 1923, ii: 739-745; and Ernest H. Starling, 'The Harveian Oration on the wisdom of the body', Lancet, 1923, ii: 865-870, 


\section{Merriley Borell}

a new etiological category for physicians and the study of the endocrine glands promised within a reasonably short period of time to establish a firm basis for the treatment of this group of disorders, the analysis of the chemical products of the endocrine glands had important and immediate applications. ${ }^{14}$ The literature quickly became unmanageable. As one reviewer of Schäfer's text, The endocrine organs, observed in 1916: "To attempt to follow the recent literature is to subject your brain to the experiences of a shuttlecock which is buffeted from one battledore to another until it falls featherless to the ground. After such stupefying aerial adventures, endured over a protracted period, the relief to find yourself once more on solid ground is quite inexpressible." 15 By encouraging the rigorous study of the anatomy and physiology of the endocrine organs by his fellow-scientists, Schäfer provided this solid ground.

One cannot properly attribute to Schäfer the establishment of a school of endocrinology either at University College or at Edinburgh. ${ }^{16}$ His passion was physiology, and endocrinology was but one aspect, albeit an important one, of the New (chemical) Physiology emerging in the early twentieth century. ${ }^{17}$ To Schäfer, physiology was the basis upon which both medicine and surgery were founded. Neither medicine nor surgery was served by speculative physiology, as for many years endocrine investigations remained. Internal secretions could not be isolated in the laboratory, although ablation and transplantation experiments, as well as pathological studies, suggested that their effects on the human body were profound. ${ }^{18}$ It is through Schäfer's efforts, that is through his own research, particularly on the adrenal and pituitary glands, and through his promotion of publication, especially from 1908 as editor of the new Quarterly Journal of Experimental Physiology, that the study of internal secretions was not cast from the legitimate domain of physiology. ${ }^{19}$ There were indeed many in

\footnotetext{
14 As regards this recognition, compare Starling's 'Harveian Oration' of 1923 with his 'Croonian Lectures' of 1905. It is in the first Croonian Lecture that Starling introduced the term 'hormone'.

${ }^{16}$ The Medical Press, 14 May 1916, p. 461 ; Schäfer's own Scrapbook of Cuttings (Book II, p. 41), Sharpey-Schafer Collection, Wellcome Institute for the History of Medicine, London. The endocrine organs, appeared in 1916, as an elaboration of his earlier work, An introduction to the study of the endocrine glands and internal secretions, Stanford, California, Stanford University Press, 1914. A second edition was published in two parts in 1924 and 1926.

${ }^{16}$ The founding of a school of physiology has been attributed to Schäfer, since his students held posts across the globe, i.e., at Belfast, New Zealand, St. Andrews, New York, Cambridge, Montreal, Glasgow, Cape Town, Dublin, Gibraltar, and London; cf. 'Obituary: Sir Edward Sharpey-Schafer, F.R.S.', Nature, Lond., 1935, 135: 610.

${ }^{17}$ Schäfer argued in 'Endocrine physiology' (op. cit., note 3 above): "The Old Physiology was based, as we have seen on nervous regulation; the New Physiology is based on chemical regulation." (p. 484) ... "The changes in physiology which have resulted from this knowledge constitute not merely an advance in degree but an alteration in character. The doctrine of internal secretion forms a new departure. We must in future explain physiological changes in terms of chemical regulation as well as of nervous regulation" (p. 505). Although this distinction was first made by Starling in his Croonian Lectures of 1905, Schäfer appears to have introduced the terms "Old" and "New" physiology.

1s Cf. note 11 above.

10 Francis Gotch, W. D. Halliburton, C. H. Sherrington, E. H. Starling, and A. D. Waller assisted Schäfer on the editorial board. Sherrington has recalled: Schäfer "allowed contributors unusual freedom of exercise of their own judgment. "Their readers are their judges, he would say, not I"' (Sherrington, 'Sir Edward Sharpey-Schafer, 1850-1935', op. cit., note 10 above, p. 103).
} 


\section{Edward Schäfer and endocrinology}

Britain who associated organ extracts with quacks, charlatans, and enterprising drug firms, and who would have preferred to ignore the claims of cure by these crude glandular preparations.

The rejuvenation studies of first Brown-Séquard in the 1890s, and later of Steinach in the 1910s, and Voronoff in the 1920s had surprisingly little visible impact on the direction of British endocrinology. Under the leadership of Schäfer and his younger colleagues, Starling, Bayliss, J. N. Langley, J. S. Haldane, C. S. Sherrington, F. G. Hopkins, and Benjamin Moore, the co-ordination of physiological events by means of chemical messengers or hormones, that is, the active principles of the internal secretions, became a problem of fundamental concern to physiologists, and the rational control of physiological events remained the goal of scientific medicine. From 1904, no less an organization than the British Association for the Advancement of Science began to provide research grants for the study of internal secretions. The chairman of the Committee on the Ductless Glands was Schäfer; the secretary, his former student and assistant Swale Vincent (1868-1933). Over one-quarter of all British Association funds allocated for research in physiology during the years 1904-1920 were granted to such studies. ${ }^{20}$

In 1910, following work at Edinburgh on the internal secretions of the ovaries, one of Schäfer's protégés, F. H. A. Marshall (1878-1949), published the first text completely devoted to discussion of the physiology of reproduction. ${ }^{21}$ Two years later, Vincent published the first English text on internal secretions. ${ }^{22}$ Each of these works bore a preface by Schäfer, and each carried an acknowledgement to Schäfer by its author. Schäfer's own contribution, An introduction to the study of the endocrine glands and internal secretions, appeared in $1914 .^{23}$ Two years later he published the revised and much extended volume, The endocrine organs.

There was little fanfare in any of these publications. Indeed considering the general

${ }^{20}$ Endocrine research received $£ 438$ of the $£ 1,575$ allocated to Section I (Physiology) during the years 1904-1920. I have calculated these figures from data compiled from the annual Report of the British Association for the Advancement of Science between 1896 and 1938. The data of O. J. R. Howarth found in The British Association for the Advancement of Science: a retrospect 1831-1931, London, B.A.A.S., 1931, p. 277, are indicative but incomplete, and I am grateful to Peter Collins of the Science Education Centre of Leeds University for helping me locate the precise figures. Note that membership of the committee changed every few years, but A. B. Macallum, Schäfer, and Vincent, were consistent members through its most active years. The committee appears to have disbanded after 1932.

${ }^{81}$ Francis H. A. Marshall, The physiology of reproduction, London, Longmans, Green, 1910. A second edition appeared in 1922. Marshall, later Reader in Agricultural Physiology at Cambridge, was greatly influenced by Schäfer between 1903 and 1908 while at Edinburgh. See A. S. Parkes, 'Francis Hugh Adam Marshall 1878-1949', Obit. Not. Fell. R. Soc. Lond., 1950-51, 7: 239-251. I discuss Marshall's role in the development of reproductive physiology in 'Origins of modern research on fertility and reproduction: physiologists and the discovery of hormones, 1889-1930', American Academy of Arts and Sciences' conference entitled "Historical perspectives on the scientific study of fertility in the United States", Boston, December 8-10 1977 (proceedings forthcoming).

${ }_{22}$ Swale Vincent, Internal secretion and the ductless glands, London, Edward Arnold, 1912. The second edition appeared in 1922. For a summary of Vincent's career, consult Who Was Who, 19291940, pp. 1391-1392, and the obituary in Nature, Lond., 1934, 133: 128-129. Biedl's text was first translated into English in 1913.

${ }^{23}$ This book was based on Schäfer's Lane Medical Lectures at Leland Stanford, Jr. University, in San Francisco, California, in 1913. Correspondence relating to these lectures, as well as the original programme, may be found in the Sharpey-Schafer Collection at the Wellcome Institute, London. 


\section{Merriley Borell}

excitement generated by the claims of organotherapy, as well as by the rejuvenationists, one is surprised, almost disappointed, by the caution and reserve of Schäfer and his students. The reviewer of Schäfer's edition of 1916 concluded: "Sir Edward Schafer, as becomes his professional status, gives us physiology pure and simple; with philosophy, in these pages at any rate, he has no truck." The reviewer was expecting insight into the "many large and burning social and political questions which still await solution."24 He was, of course, referring to debates on women's rights, eugenics, and perhaps family limitation, issues in which commentators increasingly turned to physiology for guidance and insight, insight which physiology was by no means yet prepared to provide. ${ }^{25}$

Frequently, in defence against the antivivisectionists, Schäfer commented on "the defects of mere clinical observation, unassisted by experiments on animals." ${ }^{26}$ Facts which could not be established in the laboratory were not facts; they were merely suggestive observations. ${ }^{27}$ This was true especially for the study of internal secretions. Although from 1895, it was clear to Schäfer that there were specific discoverable substances which produced profound and important effects on the human body, he was able to couple consciousness of the potential significance of clinical data with a clear scepticism of its force in proving the existence of internal secretions. ${ }^{28}$ The role of these substances in shaping the human physiology, much less the human psyche, was not at all clear, and Schäfer remained outside the arena of public debate on such questions. ${ }^{29}$

Schäfer's long-time friend and colleague, the neurologist Charles Sherrington (1857-1952), observed that Schäfer was "lifelong an enthusiast", but "he was yet an enthusiast who had his enthusiasms under cool intellectual control."30 As such, Schäfer was able to remain an advocate for endocrinology during what Hans Lisser has called the years of drought: "When his [Brown-Séquard's] claims were not confirmed, ridicule and abuse were heaped upon him, and a drought descended upon the field of clinical endocrinology which persisted with but a few scattered refreshing

See note 15 above.

25 See Diana Long Hall, 'Biology, sex hormones and sexism in the 1920s', Phil. Forum., 1973-74, 5: 81-96, for a discussion of this dilemma.

26 'Sir Edward Sharpey-Schafer, F.R.S., L.L.D., M.D., D.Sc., F.R.C.P. Ed.', The fight against disease, 1935, 23: 25.

${ }^{27}$ Schäfer's almost severe emplricism is indicated by a quote from the Edinburgh Evening News, 7 March 1922: "His [Schäfer's] powerful austere presence commands silence, and his lectures are clear, cold, and unadorned by any attempts to interest the hearer except by the logical statement of fact. Like a solemn judge pronouncing perpetual sentences of death, Sir Edward Schafer unfolds the mysteries of physiology to a crowd of undergraduates temporarily hushed." Schäfer's own Scrapbook of Cuttings (No. 5), Sharpey-Schafer Collection, Wellcome Institute, London. See also note 32 below.

${ }^{28}$ See Edward A. Schäfer, 'Address in'physiology on internal secretions', Lancet, 1895, ii: 321-324.

20 The one possible exception is an address which Schäfer delivered to the Annual Meeting of the Medico-Psychological Association in 1922. Cf. Sir E. Sharpey-Schafer, 'The influence of the internal secretions on the nervous system', J. ment. Sci., 1922, 68: 347-367. As Diana Hall has reminded me, Schäfer was not so cautious regarding the physical basis of life. See his British Association for the Advancement of Science presidential address, Life: its nature, origin, and maintenance, London, Longmans, Green, 1912.

20 Sherrington, 'Sir Edward Sharpey-Schafer, 1850-1935', op. cit., note 10 above, p. 102. 


\section{Edward Schäfer and endocrinology}

contributions for almost 30 years." 31 By demanding that endocrinology be an experimental science, Schäfer ensured its respectability as a field within physiology during those years. He led younger workers in carefully accumulating and assessing the data which would finally in the 1920 s allow the active agents of the internal secretions to be isolated as specific chemical entities. ${ }^{32}$

In lectures written in the 1920s when in his seventies, Schäfer hinted that leadership in physiology could be passing from Britain. Part of the reason for this shift he attributed to better funding of the universities abroad. ${ }^{33}$ For endocrinology there is perhaps another factor which ought to be considered. In the United States, for instance, funds for endocrine investigations were forthcoming from 1922 from the newlyformed committee of the National Research Council, Committee for Research in Problems of Sex. The fruits of such funding and the collaboration of interests of clinicians, zoologists, embryologists, anatomists, psychologists, psychiatrists, sociologists, and anthropologists quickly became apparent in the isolation and characterization of the internal secretions of the sex glands. ${ }^{34}$

In Britain, social issues pertaining to sexual behaviour, eugenics, and birth control seem not to have affected the direction of British endocrinology until perhaps the end of the $1920 \mathrm{~s}^{35}$ Instead, endocrinology remained a part of the larger aspirations of professional physiologists, who claimed for themselves the leading role in the establishment of a scientific medicine in Britain. Sharpey-Schafer did not waver from that goal either in taking up the problem of internal secretions in the 1890s or in defining the standards by which it ought to be pursued during the years of drought, when therapeutic expectations clearly exceeded technical capabilities and rational medicine was threatened by premature visions of success in the isolation and identification of that new class of substances called hormones. ${ }^{36}$

Certainly, the conceptual changes wrought in physiology by the introduction of the theory of internal secretions in the 1890 s meant that previously unrelated observations had to be accumulated and reassembled in a new and meaningful way. ${ }^{37}$ The style of that compilation and reassessment in Britain was dictated in large part by

21 Hans Lisser, 'The Endocrine Society: the first forty years (1917-1957)', Endocrinology, 1967, 80: 5-28, p. 7.

32 Sherrington noted: ". . . Sharpey-Schafer was primarily a finder and dispenser of facts; he largely let theories look after themselves. Magendie described himself as 'un chiffonier du vrai'Schafer [sic] was of that kind." (Sherrington, 'Sir Edward Sharpey-Schafer and his contributions to neurology', op. cit., note 10 above, p. 396).

${ }^{32}$ Cf. Sharpey-Schafer, 'The position of physiology in medicine', op. cit., note 13 above, pp. 11-13. For a concise summary of British contributions, see Sir E. Sharpey-Schafer, 'History of physiology in Great Britain during the last hundred years', Br. med. J., 1932, ii: 781-783.

"Sophie D. Aberle and George W. Corner, Twenty-five years of sex research: history of the National Research Council Committee for Research in Problems of Sex, Philadelphia, W. B. Saunders, 1953, esp. pp. 1-33.

${ }^{25}$ Cf. National Council of Public Morals, Medical aspects of contraception, London, Martin Hopkinson, 1927, and my analysis in Borell, 'Origins of modern research on fertility and reproduction' op. cit., note 21 above, esp. note 104 .

"Sherrington has emphasized: "The prosperity of physiology as a science in this country was with him [Schäfer] a cherished aim" (Sherrington, 'Sir Edward Sharpey-Schafer, 1850-1935', op. cit., note 10 above, p. 99).

${ }^{37}$ See Borell, 'Origins of the hormone concept', op. cit., note 7 above. 


\section{Merriley Borell}

the professional ethos shared by Sharpey-Schafer and his colleagues. Experimental physiology could indeed provide a firm basis for the practice of medicine.

By 1933, in the wake of the isolation of insulin and the gonadal and pituitary hormones, that goal was at last being realized, and Herbert Evans, like SharpeySchafer, was confident that a new era had arrived. The turmoil of the early years was dismissed as Brown-Séquard's aberration, and the difficulties inherent in outlining the appropriate strategy for research were quickly forgotten as endocrinology attained maturity. ${ }^{38}$

38 These years have been referred to as the "heroic age of reproductive endocrinology". Cf. A. S. Parkes, 'The rise of reproductive endocrinology 1926-1940', J. Endocr., 1966, 34: xx. The appearance in 1936 of Rolleston's classic The endocrine organs, (op. cit., note 1 above) marks the establishment of endocrinology as a maturing science. 